\title{
Studies on Component Characters Association with Flower Yield in Chrysanthemum (Dendranthema grandiflora Tzvelve)
}

\author{
Mallikarjun Hebbal $^{1 *}$, Mukund Shiragur ${ }^{1}$, B.C. Patil ${ }^{1}$, G.K. Seetharamu ${ }^{1}$, \\ Sandhyarani Nishani ${ }^{2}$ and Mahantesha B.N. Naika ${ }^{2}$ \\ ${ }^{I}$ Department of Floriculture and Landscape Architecture, University of Horticultural \\ Sciences, Bagalkot, Karnataka, India \\ ${ }^{2}$ Department of Crop Improvement and Biotechnology, KRCCH, Arabhavi-591218, University \\ of Horticultural Sciences, Bagalkot, Karnataka, India \\ *Corresponding author
}

\begin{tabular}{|c|c|}
\hline & A B S T R A C T \\
\hline & \multirow{6}{*}{$\begin{array}{l}\text { Ten genotypes of chrysanthemum (Dendranthema grandiflora Tzvelve) were assessed for } \\
12 \text { different growth, flowering, flower yield and quality traits to study the association of } \\
\text { different parameters with flower yield per plant (g). In the present study, days to flower } \\
\text { bud initiation and number of flowers showed highly significant and positive association } \\
\text { with flower yield per plant (g) at both genotypic and phenotypic levels. Number of flowers } \\
\text { was found have highly significant negative correlation with flower diameter (cm) and } \\
\text { individual flower weight ( } \mathrm{g} \text { ) at both genotypic and phenotypic levels. However, the } \\
\text { number of flowers showed highly significant positive correlation with flower yield per } \\
\text { plant (g) at both genotypic and phenotypic levels. Shelf life (h) showed significant positive } \\
\text { correlation with flower yield per plant (g) at genotypic level only indicating that, growing } \\
\text { environment influence on flower shelf life is negligible. Hence, selection for the traits that } \\
\text { are positively associated would be effective for flower yield improvement in } \\
\text { chrysanthemum. Thus in chrysanthemum the genotype, which flower comparatively late } \\
\text { with more number of flowers (lesser flower diameter and lesser flower weight) and having } \\
\text { good shelf life of flower would increase the flower yield. }\end{array}$} \\
\hline Keywords & \\
\hline $\begin{array}{l}\text { Correlation coefficient, } \\
\text { Flower yield per plant, } \\
\text { Dendranthema } \\
\text { grandiffora Tzvelve }\end{array}$ & \\
\hline Article Info & \\
\hline $\begin{array}{l}\text { Accepted: } \\
\text { 26 July } 2018 \\
\text { Available Online: } \\
10 \text { August } 2018\end{array}$ & \\
\hline & \\
\hline
\end{tabular}

\section{Introduction}

Flowers and flowering plants are fascinating part of our life. Among them, chrysanthemum (chryos - golden; anthos - flower) called as "Queen of the East" is a most interesting and popular flower crop of commercial importance. It ranks third in the International cut flower trade next to rose and carnation in demand and popularity. Chrysanthemum is native to China, belonging to the family Asteraceae which is the most phylogenetically advanced dicotyledonous family. The inflorescence is called as capitulum or head consisting of large number of tiny florets closely mounted on a flattened stem end, which gives a false appearance of single bloom. Garden chrysanthemum which was previously known as Chrysanthemum morifolium (Ramat) and now it is called as 
Dendranthema grandiflora (Tzvelev). In India chrysanthemum commercially cultivated in states like Tamil Nadu, Karnataka, Maharashtra, Rajasthan, Madhya Pradesh and Bihar. Its cultivation is popular around the cities like Delhi, Kolkata, Lucknow, Kanpur, Chennai, Allahabad and Bengaluru. Still, there is a need to increase chrysanthemum cultivation which is limiting due to lack of high yielding varieties with attractive flowers. A study was conducted to assess the components characters correlated with flower yield in chrysanthemum.

The phenotypic expression of the plant character is mainly controlled by the genetic makeup of the plant and the environment in which it is grown plus the interaction between the genotypes and environment. Further, the genotype of the plant is controlled by different gene action i.e. additive gene effect (heritable), non-additive gene effect or dominance (non-heritable) and epistasis (nonallelic dominance). Correlation coefficient analysis measures the mutual relationship between various plant characters and determines the component characters on which selection can be based for genetic improvement in yield. Yield being a complex character, is collectively influenced by various characters which are polygenically inherited and highly subjected to environment variations. The phenotypic correlations indicate the extent of the observed relationship between two characters. This does not give true genetic picture of the relationship because it includes both heritable and non-heritable association. Genotypic correlations provide an estimate of inherent association between genes controlling any two characters. Improving genetic correlation was mainly due to pleiotrophy and linkage (Jain, 1982). Hence, for an effective and efficient selection of genotypes for yield, the knowledge of direction and magnitude of association between yield and its components and among the components themselves is very much essential. Simultaneous improvement of traits becomes difficult if there is high correlation among them.

\section{Materials and Methods}

The experiment was conducted to study the correlation of the different morphological characters influencing the flower yield in different genotypes of chrysanthemum (Dendranthema grandiflora Tzvelve). The experimental material comprised of ten chrysanthemum genotypes such as Marigold, Dall White, Karnool, Dall Yellow, Poornima Yellow, Poornima Pink, Calcutta Shantini, Poornima Red, Poornima White and Dundi were evaluated in Complete Randomized Design with three replications during kharif 2017-18 at K. R. C. College of Horticulture, Arabhavi. The plants were planted at a spacing of $60 \times 45 \mathrm{~cm}$ and all the recommended cultural practices were followed. Five competitive plants were tagged at random in each treatment in each replication for recording detailed observation and the data were recorded for all the 12 quantitative characters viz., plant height, number of primary and secondary branches, number of leaves at 90 days after planting, leaf area $\left(\mathrm{cm}^{2}\right)$, days taken for flower bud initiation, days for 50 per cent flowering, duration of flowering (days), number of flowers per plant, individual flower weight $(\mathrm{g})$, diameter of flower $(\mathrm{cm})$, shelf life $(\mathrm{h})$ and flower yield per plant ( $\mathrm{g} /$ plant) were recorded. Mean values were subjected to analysis of variance, genotypic and phenotypic correlation were estimated as suggested by Al-Jibourie et al., (1958).

\section{Results and Discussion}

The genotypic and phenotypic correlation studies were carried out for the 12 characters to know the nature of relationship existing 
between flower yield per plant (g/plant) and its other component characters (Table 1). Yield is a complex character determined by several other characters. Hence, the association of these characters with yield and among themselves is of paramount importance in framing effective selection. In general, genotypic correlation coefficients were higher than the phenotypic correlation coefficients. This indicates the presence of inherent association between various characters considered in the present study. Similar trend was observed by Raghava et al., (1992) in chrysanthemum, Anuradha and Narayanagowda (1999) and Magar et al., (2010) in gerbera for most of the characters, these finding indicates that though there is strong inherent association between various characters, the phenotypic expression is reduced under the influences of environment.

Plant height at 90 DAP had highly significant and positive correlation with number of secondary branches per plant $(0.801$ and $0.531)$, number of flowers per plant $(0.674$ and 0.566), leaf area (0.644 and 0.541) and number of leaves at 90 DAP (0.619 and 0.516) at both genotypic and phenotypic levels, respectively. It also had highly significant and negative correlation with individual flower weight $(-0.584$ and -0.521$)$ at both genotypic and phenotypic levels. Similar results were reported by Raghava et al., (1992) in chrysanthemum, Kore (2014) in China aster and Mathad et al., (2005) in marigold. Number of primary branches at 90 DAP had highly significant and significant positive correlation with shelf life of flowers (0.611) and flower diameter (0.447) at genotypic level. It also had significant positive correlation with shelf life of flowers (0.447) at phenotypic level. Number of secondary branches at 90 DAP had significant positive correlation with duration of flowering (0.425), leaf area (0.385) and number of flowers (0.376) at genotypic level. It also had highly significant negative correlation with individual flower weight (-0.916 and -0.604) at both genotypic and phenotypic level, respectively. This trend was confirmed by Misra et al., (2013) in chrysanthemum. In marigold, number of lateral branches had significantly positive association with plant spread and flower yield per plant (Janikiram and Rao, 1991 and Mathew et al., 2005) and with number of flowers per plant by Banupratap et al., (1999). Whereas, negative correlation was observed with individual flower weight.

Number of leaves at 90 DAP had highly significant and positive correlation with days to flower bud initiation (0.853 and 0.831), number of flowers (0.788 and 0.740) and days taken for fifty per cent flowering (0.666 and 0.641) at both genotypic and phenotypic levels, respectively. It also had highly significant and negative correlation with flower diameter (-0.903 and -0.850) and individual flower weight (-0.634 and -0.605$)$ at both genotypic and phenotypic levels, respectively. The findings are in line with reports by Chaugule (1985) in chrysanthemum and Kore (2014) in China aster. Leaf area had highly significant and positive correlation with flower diameter (0.519) at genotypic level. Leaf area had significant and positive correlation with shelf life $(0.381)$ at genotypic level and flower diameter (0.493) at phenotypic level. It also had significant negative correlation with days taken for fifty per cent flowering (-0.384 and -0.367) at both genotypic and phenotypic levels, respectively. Similar results were reported by Chaugule (1985) in chrysanthemum.

Days taken for flower bud initiation had highly significant and positive correlation with days taken for fifty per cent flowering $(0.857$ and 0.848), number of flowers (0.661 and $0.645)$ and flower yield per plant $(0.563$ and 0.520 ) at both genotypic and phenotypic levels, respectively. 
Table.1 Genotypic and phenotypic correlation coefficients for growth, flowering, yield and quality characters in Chrysanthemum genotypes

\begin{tabular}{|c|c|c|c|c|c|c|c|c|c|c|c|c|c|c|}
\hline & & $\mathbf{X 1}$ & $\mathbf{X} 2$ & $\mathbf{X 3}$ & $\mathrm{X} 4$ & X5 & X6 & $\mathbf{X 7}$ & X8 & X9 & $\mathrm{X} 10$ & X11 & $\mathrm{X} 12$ & X13 \\
\hline \multirow{2}{*}{$\mathrm{X} 1$} & G & 1 & 0.297 & $0.801 * *$ & $0.619 * *$ & $0.644 * *$ & 0.251 & 0.129 & 0.289 & $0.674 * *$ & $-0.584 * *$ & -0.259 & 0.130 & 0.282 \\
\hline & $\mathbf{P}$ & 1 & 0.236 & $0.531 * *$ & $0.516 * *$ & $0.541 * *$ & 0.210 & 0.104 & 0.232 & $0.566 * *$ & $-0.521 * *$ & -0.229 & 0.103 & 0.205 \\
\hline \multirow[t]{2}{*}{$\mathbf{X} 2$} & G & & 1 & 0.297 & -0.158 & 0.319 & -0.216 & -0.084 & -0.293 & -0.291 & 0.053 & $0.447 *$ & $0.611^{* *}$ & -0.104 \\
\hline & $\mathbf{P}$ & & 1 & 0.341 & -0.186 & 0.285 & -0.173 & -0.048 & -0.166 & -0.262 & 0.038 & 0.344 & $0.447 *$ & -0.133 \\
\hline \multirow[t]{2}{*}{$\mathbf{X 3}$} & G & & & 1 & 0.289 & $0.385^{*}$ & -0.250 & $-0.412 *$ & $0.425 *$ & $0.376^{*}$ & $-0.916^{* *}$ & 0.030 & -0.344 & -0.342 \\
\hline & $\mathbf{P}$ & & & 1 & 0.188 & 0.336 & -0.210 & -0.302 & 0.349 & 0.306 & $-0.604 * *$ & 0.073 & -0.283 & -0.153 \\
\hline \multirow[t]{2}{*}{$\mathrm{X} 4$} & G & & & & 1 & -0.213 & $0.853 * *$ & $0.666 * *$ & 0.257 & $0.788 * *$ & $-0.634 * *$ & $-0.903 * *$ & -0.091 & 0.294 \\
\hline & $\mathbf{P}$ & & & & 1 & -0.210 & $0.831 * *$ & $0.641 * *$ & 0.207 & $0.740 * *$ & $-0.605^{* *} *$ & $-0.850 * *$ & -0.080 & 0.260 \\
\hline \multirow[t]{2}{*}{$\mathrm{X5}$} & G & & & & & 1 & -0.360 & $-0.384 *$ & -0.094 & 0.138 & 0.108 & $0.519 * *$ & $0.381 *$ & 0.352 \\
\hline & $\mathbf{P}$ & & & & & 1 & -0.351 & $-0.367 *$ & -0.089 & 0.133 & 0.111 & $0.493 *$ & 0.340 & 0.332 \\
\hline \multirow[t]{2}{*}{ X6 } & G & & & & & & 1 & $0.857 * *$ & -0.204 & $0.661 * *$ & -0.201 & $-0.841 * *$ & 0.166 & $0.563 * *$ \\
\hline & $\mathbf{P}$ & & & & & & 1 & $0.848 * *$ & -0.197 & $0.645^{* *}$ & -0.206 & $-0.826 * *$ & 0.164 & $0.520 * *$ \\
\hline \multirow[t]{2}{*}{$\mathrm{X7}$} & G & & & & & & & 1 & -0.201 & 0.306 & -0.033 & $-0.667 * *$ & $0.409 *$ & 0.281 \\
\hline & $\mathbf{P}$ & & & & & & & 1 & -0.172 & 0.302 & -0.026 & $-0.647 * *$ & $0.393 *$ & 0.273 \\
\hline \multirow[t]{2}{*}{$\mathbf{X 8}$} & G & & & & & & & & 1 & -0.039 & $-0.510 * *$ & -0.290 & $-0.567 * *$ & $-0.652 * *$ \\
\hline & $\mathbf{P}$ & & & & & & & & 1 & -0.031 & $-0.458 *$ & -0.282 & $-0.547 * *$ & $-0.573 * *$ \\
\hline \multirow[t]{2}{*}{ X9 } & G & & & & & & & & & 1 & $-0.588 * *$ & $-0.647 * *$ & -0.212 & $0.615 * *$ \\
\hline & $\mathbf{P}$ & & & & & & & & & 1 & $-0.557 * *$ & $-0.624 * *$ & -0.200 & $0.620 * *$ \\
\hline \multirow[t]{2}{*}{$\mathrm{X} 10$} & G & & & & & & & & & & 1 & $0.471 * *$ & $0.513 * *$ & 0.242 \\
\hline & $\mathbf{P}$ & & & & & & & & & & 1 & $0.463 * *$ & $0.473 * *$ & 0.271 \\
\hline \multirow[t]{2}{*}{$\mathrm{X} 11$} & G & & & & & & & & & & & 1 & 0.282 & -0.203 \\
\hline & $\mathbf{P}$ & & & & & & & & & & & 1 & 0.275 & -0.176 \\
\hline \multirow[t]{2}{*}{$\mathrm{X} 12$} & G & & & & & & & & & & & & 1 & $0.365^{*}$ \\
\hline & $\mathbf{P}$ & & & & & & & & & & & & 1 & 0.326 \\
\hline
\end{tabular}

* Significant at $\mathrm{p}=0.05$ probability $(0.361) ; * *$ significant at $\mathrm{p}=0.01$ probability $(0.463)$

\begin{tabular}{|c|c|c|c|}
\hline X1: Plant height (90 DAP) (cm) & $\begin{array}{l}\text { X2: Number of primary branches }(90 \\
\text { DAP) }\end{array}$ & $\begin{array}{l}\text { X3: Number of secondary branches ( } 90 \\
\text { DAP) }\end{array}$ & X4: Number of leaves (90 DAP) \\
\hline X5: Leaf area $\left(\mathrm{cm}^{2}\right)$ & X6: Days to flower bud initiation & X7: Days to fifty per cent flowering & X8: Duration of flowering (days) \\
\hline X9: Number of flowers per plant & X10: Individual flower weight (g) & X11: Flower diameter $(\mathrm{cm})$ & X12: Shelf life (h) \\
\hline X13: Flower yield per plant (g) & G: Genotypic correlation value & P: Phenotypic correlation value & \\
\hline
\end{tabular}


It also had highly significant and negative correlation with flower diameter $(-0.841$ and 0.826) at both genotypic and phenotypic levels, respectively. The results are in conformity with Thirakannavar et al., (2015) in China aster for days to flower commencement.

Days taken for fifty per cent flowering had significant and positive correlation with days shelf life of flowers (0.409 and 0.393) at both genotypic and phenotypic levels, respectively. It also had highly significant and negative correlation with flower diameter $(-0.667$ and 0.647) at both genotypic and phenotypic levels, respectively. The results are in conformity with Thirakannavar et al., (2015) in China aster.

Duration of flowering had highly significant and negative correlation with flower yield per plant $(-0.652$ and -0.573$)$ counter results were found by Shanmugam et al., (1972) in chrysanthemum and Kore (2014) in China aster. Similarly highly significant and negative correlation with shelf life $(-0.567$ and -0.547$)$ at both genotypic and phenotypic levels, respectively. Duration of flowering exhibited negative significant association with shelf life, which is in line with the findings of Mathew et al., (2005) in African marigold and Sahu and Sharma (2014) in chrysanthemum. While, it had highly significant negative correlation with individual flower weight ($0.510)$ at genotypic level and (-0.458) at phenotypic level, respectively.

Flower diameter had highly significant and positive correlation with leaf area (0.519 and $0.493)$ and individual flower weight $(0.471$ and 0.463 ) at both genotypic and phenotypic levels, respectively. Similar results were reported by Patil and Rane (1994), Ashwath and Parthasarathy (1993), Patil and Rane (1994), Ravikumar and Patil (2003) and Kore (2014) in China aster and by Singh et al.,
(2008) in marigold. It also had highly significant and negative correlation with number of flowers per plant $(-0.647$ and $0.624)$ at both genotypic and phenotypic levels, respectively. Since flower diameter is very important character, indirect selection for this trait should be considered for increasing the diameter of flower.

Number of flowers per plant had highly significant and positive correlation with flower yield per plant (0.615 and 0.620) at both genotypic and phenotypic levels, respectively. Similar results were reported by Rao (1982); Negi et al., (1983); Ashwath and Parthasarathy (1993) and Sreenivasulu et al., (2007) in China aster; Pandita and Bhan (1989), Sirohi and Behera (1999) and Shiragur (2012) in chrysanthemum.

It also had highly significant and negative correlation with flower diameter $(-0.647$ and $0.624)$ and individual flower weight (-0.588 and -0.557$)$ at both genotypic and phenotypic levels, respectively. Whereas, significant and negative correlation with individual flower weight, these result is line with Baskaran et al., (2004), Roein et al., (2015) in chrysanthemum.

Individual flower weight had highly significant and positive correlation with shelf life (0.513 and 0.473) and flower diameter (0.471 and 0.463) at both genotypic and phenotypic levels, respectively. Similarly weight of flowers per plant in chrysanthemum had significant positive correlations with shelf life of flowers were noticed by Chaugule (1985) and by Kore (2014) in China aster.

Shelf life had significant and positive correlation with flower yield per plant $(0.365)$ at genotypic level. Shelf life had significant negative correlation with duration of flowering. The results are in conformity with Sahu and Sharma (2014). 
In the present study, days to flower bud initiation and number of flowers showed highly significant and positive association with flower yield per plant (g) at both genotypic and phenotypic levels. Number of flowers was found have highly significant negative correlation with flower diameter $(\mathrm{cm})$ and individual flower weight $(\mathrm{g})$ at both genotypic and phenotypic levels. However, the number of flowers showed highly significant positive correlation with flower yield per plant (g) at both genotypic and phenotypic levels. These characters showed significant contribution in increasing the flower yield in chrysanthemum which is heritable and environmental influence also. But, the parameter, shelf life (h) showed significant positive correlation with flower yield per plant (g) at genotypic level only indicating that, growing environment influence on flower shelf life is negligible. Hence, selection for the traits that are positively associated would be effective for flower yield improvement in chrysanthemum. Thus in chrysanthemum the genotype which flower comparatively late with more number of flowers and having good shelf life of flower would increase the flower yield ( $\mathrm{g}$ ).

\section{References}

Al-Jibourie, H. A., Miller, P. A. and Robinson, H. F., 1958, Genetic and environmental variance in an upland cotton cross on inter-specific origin. Agron. J., 50: 633-637.

Anuradha, S. and Narayanagowda, J. V., 1999, Quantitative genetic studies in gerbera. Mysore J. Agric. Sci., 33 (2): 224-227.

Ashwath, C. and Parthasarathy, V. A., 1993, Heritability and correlation studies in China aster (Callisthephus chinensis [Ness.]). Indian J. Hort., 50 (1): 89-92.

Baskaran, V., Janakiram, T. and Jayanthi, R., 2004, Correlation and path analysis studies in chrysanthemum. J. Orn. Hort., 7 (3-4): 37-44.

Bhanupratap, G. N., Tewari and Mishra, L. N., 1999, Correlation studies in marigold. J. Orn. Hort. (New series), 2 (2): 84-88.

Chaugule, B. B., 1985, Studies on genetic variability in chrysanthemum (Chrysanthemum morifolium). M. Sc. (Agri) Thesis, Mahatma Phule Agril. Univ., Rahuri.

Jain, S. P., 1982, Statistical techniques in quantitative genetics. Indian agricultural statistics research institute, New Delhi.

Janakiram, T. and Rao, T. M., 1991, Genetic improvement of marigold. In Floriculture Technology, Trade and Trends. Ed. Prakash, J and Bhandary, K. R., Oxford and IBH Company Private Limited, New Delhi, pp. 331335.

Kore, R., 2014, Studies on genetic variability and molecular characterization in China aster (Callistephus chinensis [L.] Nees.). M. Sc. (Hort.) Thesis. UHS Bagalkot.

Magar, S. D., Warade, S. D., Nalge, N. A. and Nimbalkar, C. A., 2010, Correlation and path analysis studies in gerbera (Gerbera jamesonii). Int. J. Plant Sci. 5 (2): 553-555.

Mathad, G., Hegde, Reddy B. S. and Mulge, R., 2005, Correlation and path coefficient analysis in African marigold (Tagetes erecta L.). The Karnataka J. Hort., 1 (3): 22-29.

Mathew, R., Hatia, S. K., Beniwal, B. S. and Deswal, D. P., 2005, Correlation and path analysis in flower production and seed yield in marigold. National symposium on recent trend and future strategies. J. Orn. Hort. pp: 105-108.

Misra. S., Mandal. T., Vanlalruati. and Das. S. K. 2013, Correlation and path coefficient analysis for yield contributing parameters in spray 
chrysanthemum. J. Hort. Letters. 3(1): 14-16.

Negi, S. S., Ragava, S. P. S., Sharma, T. V. R. S. and Sreenivasan, R. R., 1983, Studies on variability and correlation in China aster. Indian J. Hort, 40: 102-106.

Pandita, P. N. and Bhan, M. K., 1989, Genotypic and phenotypic correlations in pyrethrum. Pesticides, 23 (2): 28-29.

Patil, S. S. D. and Rane, D. A., 1994, Correlation and path coefficient analysis in China aster. J. Maharastra Agric. Univ., 19 (3): 375-377.

Raghava, S. P. S., Negi, S. S. and Nancharaiah, D., 1992, Genetic variability, correlation and path-analysis in chrysanthemum. Indian J. Hort., 49 (2): 200-204.

Rao, M. T. 1982, Studies on genetic variability and correlation in China aester (Callisthephus chinensis Nees.). M. Sc. (Hort.) Thesis Univ. Agril. Sci., Bangalore.

Ravikumar, H. and Patil, V. S., 2003, Genetic variability and character association studies in China aster (Callistephus chinensis) genotypes. J. Orn. Hort., 6(3): 222- 228.

Roein, Z., Asil, M, H. and Sabouri, A., 2015, Identification of AFLP markers associated with flowering time and ornamental traits in chrysanthemum. Iran. J. Gen. Plt. Breed. 4(2): 37-46.

Sahu, M. and Sharma, G., 2014, Genetic variability, correlation and path analysis for yield and its attributing traits in small flowered chrysanthemum. J. Orn. Hort. 17 (1\&2): 32-37.

Shanmugam, A., Muthuswamy, S. and Srinivasan, N., 1972, Inter relationship between yield and certain growth and floral attributes in two chrysanthemum varieties (Chrysanthemum indicum L.). South Indian Hort., 36: 30-31.

Shiragur, M., 2009, Characterization of chrysanthemum (Dendranthema grandiflora Tzvelev.) germplasm through morphological and molecular markers, Ph. D Thesis Univ. Agril. Sci., Bangalore.

Singh, D. and Kumar. S., 2008, Studies on genetic variability, heritability, genetic advance and correlation in marigold. $J$. Orn. Hort., 11(1): 27-31.

Sirohi, P. S. and Behera, T. K., 1999, Correlation and path analysis studies in chrysanthemum. J. Orn. Hort., New Series, 2(2): 80-83.

Sreenivasulu, G. B., Kulkarni, B. S., Natraj, S. K., Reddy, B. S., Naik, K. M. and Chandan. K., 2007, Correlation studies for yield and yield contributing characters in China aster (Callistephus chinensis). Asian J. Hort., 2(2): 192194.

Tirakannanavar, S., Katagi, A., Jagadeesha, R. C. and Halesh, G. K., 2015, Studies on genotypic evaluation and correlation studies in China aster [Callistephus chinensis (L.) Nees.]. Indian Res. J. Genet. \& Biotech. 7(2): 179 - 186.

\section{How to cite this article:}

Mallikarjun Hebbal, Mukund Shiragur, B.C. Patil, G.K. Seetharamu, Sandhyarani Nishani and Mahantesha B.N. Naika. 2018. Studies on Component Characters Association with Flower Yield in Chrysanthemum (Dendranthema grandiflora Tzvelve). Int.J.Curr.Microbiol.App.Sci. 7(08): 4508-4514. doi: https://doi.org/10.20546/ijcmas.2018.708.477 